Article

\title{
Cytotoxic Podophyllotoxin Type-Lignans from the Steam Bark of Bursera fagaroides var. fagaroides
}

Andrés M. Rojas-Sepúlveda ${ }^{1}$, Mario Mendieta-Serrano ${ }^{2}$, Mayra Y. Antúnez Mojica ${ }^{1}$, Enrique Salas-Vidal ${ }^{2}$, Silvia Marquina ${ }^{1}$, María Luisa Villarreal ${ }^{3}$, Ana María Puebla ${ }^{4}$, Jorge I. Delgado ${ }^{4}$ and Laura Alvarez ${ }^{1, *}$

1 Centro de Investigaciones Químicas, Universidad Nacional Autónoma de México, Cuernavaca, Morelos 62209, Mexico; E-Mails: amrojas@uaem.mx (A.M.R.-S.); antunezmayra@gmail.com (M.Y.A.-M.); smarquina21@hotmail.com (S.M.)

2 Departamento de Fisiología Molecular y Genética del Desarrollo, Instituto de Biotecnología, Universidad Nacional Autónoma de México, Cuernavaca, Morelos 62250, Mexico;

E-Mails: msma@ibt.unam.mx (M.M.-S.); esalas@ibt.unam.mx (E.S.-V.)

3 Centro de Investigación en Biotecnología, Universidad Autónoma del Estado de Morelos, Cuernavaca, Morelos 62209, Mexico; E-Mail: luisav@uaem.mx

4 Departamento de Farmacobiología, Centro Universitario de Ciencias Exactas e Ingeniería, Universidad de Guadalajara, Guadalajara, Jalisco 44430, Mexico;

E-Mails: ampuebla@cencar.udg.mx (A.M.P.); ivanovith@yahoo.com (J.I.D.)

* Author to whom correspondence should be addressed; E-Mail: lalvarez@ciq.uaem.mx; Tel.: +52-777-329-7997; Fax: +52-777-329-7998.

Received: 28 June 2012; in revised form: 3 August 2012 / Accepted: 3 August 2012 / Published: 9 August 2012

Abstract: The hydroalcoholic extract of the steam bark of B. fagaroides var. fagaroides displayed potent cytotoxic activity against four cancer cell lines, namely $\mathrm{KB}$ $\left(\mathrm{ED}_{50}=9.6 \times 10^{-2} \mu \mathrm{g} / \mathrm{mL}\right), \mathrm{PC}-3\left(\mathrm{ED}_{50}=2.5 \times 10^{-1} \mu \mathrm{g} / \mathrm{mL}\right), \mathrm{MCF}-7\left(\mathrm{ED}_{50}=6.6 \mu \mathrm{g} / \mathrm{mL}\right)$, and HF-6 $\left(\mathrm{ED}_{50}=7.1 \times 10^{-3} \mu \mathrm{g} / \mathrm{mL}\right)$. This extract also showed anti-tumour activity when assayed on mice inoculated with L5178Y lymphoma cells. Bioactivity-directed isolation of this extract, afforded seven podophyllotoxin-type lignans identified as podophyllotoxin (1), $\beta$-peltatin-A-methylether (2), 5'-desmethoxy- $\beta$-peltatin-A-methylether (3), desmethoxyyatein (4), desoxypodophyllotoxin (5), burseranin (6), and acetyl podophyllotoxin (7) by $1 \mathrm{D}$ and 2DNMR and FAB-MS analyses, and comparison with reported values. All the isolated compounds showed potent cytotoxic activity in the cell lines tested, especially compound $\mathbf{3}$, which exhibited greater activity than camptothecin and podophyllotoxin against 
PC-3 $\left(\mathrm{ED}_{50}=1.0 \times 10^{-5} \mu \mathrm{g} / \mathrm{mL}\right)$, and $\mathrm{KB}\left(\mathrm{ED}_{50}=1.0 \times 10^{-5} \mu \mathrm{g} / \mathrm{mL}\right)$. This is the first report of the isolation of podophyllotoxin and its acetate in a Bursera species.

Keywords: Bursera fagaroides var. fagaroides; lignans; podophyllotoxin; cytotoxic activity; antitumoral

\section{Introduction}

Podophyllotoxin (1) is one of the well-known bioactive naturally occurring aryltetralin lignans. This compound and its derivatives have great significance because of its biological activities, mainly as strong antineoplastic drugs and antiviral agents. Many semisynthetic derivatives of $\mathbf{1}$, developed and tested for anticancer activity, have resulted in the commercial production of three glucosidic cyclic acetals of epipodophyllotoxin, that is, etoposide, teniposide, and etopophos. They are currently used in chemotherapy for various types of cancer, including small cell lung cancer, testicular carcinoma, lymphoma, and Kaposi's sarcoma [1-3]. Some reviews on its distribution, sources, applications, synthesis and structure-activity relationship of podophyllotoxin have been published $[1,4,5]$.

The genus Bursera (Burseraceae), which comprises approximately 100 species distributed from the southwestern United States to Peru, predominates in the tropical dry forests of México where about 85 species coexist and some 75 of them are endemic [6-8]. Several species produce an aromatic resin known as "copal", which has been commonly burnt as incense in religious activities all over the country since ancient times [9,10]. The chemical profile of these plants includes flavonoids [11,12], triterpenes [13,14], sesquiterpenes [15,16], diterpenes [17], and lignans [18-27].

In Mexican traditional medicine a taxa complex of three Bursera fagaroides varieties $(B$. fagaroides var. fagaroides, B. fagaroides var. elongata and B. fagaroides var. purpusii) is described [28], which are reputed to have antitumor activity [29,30]. These are wild trees endemic to México and known as "aceitillo", "copal" and "cuajiote amarillo". Previous studies made on B. fagaroides, without specifying the variety studied, demonstrated that the chloroform extract showed antitumoral activity in the Walker carcinoma 256 tumor system WA16 [18], and the ethanol extract showed immunomodulator and antitumoral activities in the mouse lymphoma L5178Y cell line [31]. On the other hand, the ethanol extract from the bark of this plant affects the levels of polyamines, as well as the activity of the enzyme ornithine decarboxylase (ODC) in vitro and on the growth of Entamoeba histolytica [32]. It was also studied for its immobilization and agglutination effects on human and mouse spermatozoa [33]. Two lignans, $\beta$-peltatin-A-methylether (2) and 5'-desmethoxy- $\beta$-peltatin-Amethylether (3) from this plant were active against the WA16 tumor system [18]. Recently four podophyllotoxin related lignans, including deoxypodophyllotoxin, morelensin, yatein, and desmethoxy-yatein, were isolated from the cytotoxic ethanol extract of the dried exudates [19].

On the basis of the therapeutic potential of this plant as herbal drug, and in order to define its cytotoxic potential, we undertook a bioassay-guided isolation of the cytotoxic principles present in the hydroalcoholic extract obtained from the stem bark of one of the three varieties of this complex: B. fagaroides var. fagaroides. 
In this paper we report on the antitumor and potent cytotoxic activities of the hydroalcoholic extract (HA) of the steam bark of B. fagaroides var. fagaroides. Purification of this extract by bioassay-guided chromatographic methods afforded seven podophyllotoxin-type lignans, which showed important cytotoxic activities against KB (nasopharyngeal), HF-6 (colon), MCF-7 (breast), and PC-3 (prostate) cancer cell lines with $\mathrm{ED}_{50}$ values comparable to those displayed by camptothecin, podophyllotoxin and etoposide used as positive controls.

\section{Results and Discussion}

The intraperitoneal administration of 50 and $100 \mathrm{mg} / \mathrm{Kg}$ of the hydroalcoholic extract of the bark of B. fagaroides var. fagaroides (HA), on mice inoculated with $2 \times 10^{4}$ L5178Y lymphoma cells/mouse, showed an increase on the survival time (Figure 1). Mice with $2 \times 10^{4}$ L5178Y cells usually die within 30 days without treatment. When treated with the dose of $100 \mathrm{mg} / \mathrm{Kg}$ of HA extract over 15 days, the survival was significantly prolonged $(p<0.001)$ compared with the control groups. Median survival time for the group without HA treatment was of 29 days, while for those that received the dose of 50 and $100 \mathrm{mg} / \mathrm{Kg}$, this time increased to 35 and 38 days, respectively. The survival of the $100 \mathrm{mg} / \mathrm{Kg}$ group was $50 \%$ better than the $50 \mathrm{mg} / \mathrm{Kg}$ group $(p<0.05)$. The best response was observed with the $100 \mathrm{mg} / \mathrm{Kg} /$ day dose, where the survival of treated mice was significantly prolonged ( $p<0.001)$ compared with the placebo and control groups. This dose cured $26 \%$ of the treated mice. Survival for more than 60 days without a tumor was considered to be a 'cure' [31]. On the other hand, this extract also significantly inhibited the proliferation of $\mathrm{KB}\left(\mathrm{ED}_{50}=9.6 \times 10^{-2} \mu \mathrm{g} / \mathrm{mL}\right), \mathrm{PC}-3$ $\left(\mathrm{ED}_{50}=2.5 \times 10^{-1} \mu \mathrm{g} / \mathrm{mL}\right), \mathrm{HF}-6\left(\mathrm{ED}_{50}=7.1 \times 10^{-3} \mu \mathrm{g} / \mathrm{mL}\right)$ and MCF-7 $\left(\mathrm{ED}_{50}=6.6 \mu \mathrm{g} / \mathrm{mL}\right)$ tumor cell lines (Table 1).

Figure 1. Antitumor activity of Bursera fagaroides var. fagaroides HA extract evaluated for the survival rate of mice with lymphoma L5178Y, comparing the control groups (without or placebo treatments) and versus treated groups with 50 and $100 \mathrm{mg} / \mathrm{Kg} / \mathrm{day} / 15$ days $(n=10)$. All of them by Kaplan-Maier estimation of survival were different $(p<0.001)$.

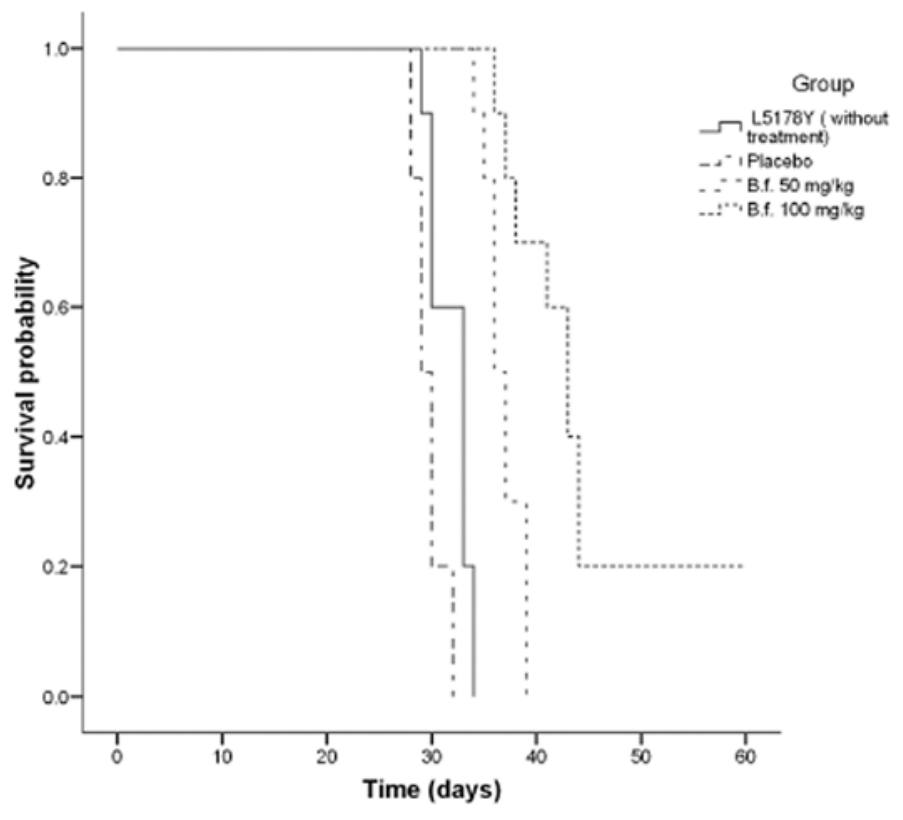


Table 1. $\mathrm{ED}_{50}$ Values $(\mu \mathrm{g} / \mathrm{mL})$ of Extract, Fractions, and Active Compounds Isolated from $B$. fagaroides var. fagaroides against four human cancer cell lines.

\begin{tabular}{ccccc}
\hline Compound & KB & PC-3 & MCF-7 & HF-6 \\
\hline HA & $9.6 \times 10^{-2} \pm 0.07$ & $2.5 \times 10^{-1} \pm 0.03$ & $6.6 \pm 0.01$ & $7.1 \times 10^{-3} \pm 0.1$ \\
F-1 & $6.0 \times 10^{-3} \pm 0.08$ & $1.0 \times 10^{-5} \pm 0.006$ & $8.8 \times 10^{-1} \pm 0.03$ & $4.3 \times 10^{-3} \pm 0.04$ \\
$\mathbf{F - 2}$ & $1.3 \times 10^{-1} \pm 0.02$ & $1.0 \times 10^{-5} \pm 0.004$ & $8.2 \times 10^{-1} \pm 0.03$ & $3.6 \times 10^{-2} \pm 0.02$ \\
$\mathbf{F - 1 - 1}$ & $3.94 \times 10^{-1} \pm 0.08$ & $1.0 \times 10^{-5} \pm 0.1$ & $8.1 \pm 0.1$ & $8.0 \times 10^{-5} \pm 0.03$ \\
$\mathbf{F - 1 - 2}$ & $3.5 \times 10^{-1} \pm 0.02$ & $7.8 \times 10^{-4} \pm 0.06$ & $1.3 \pm 0.08$ & $6.5 \times 10^{-3} \pm 0.01$ \\
$\mathbf{F - 2 - 1}$ & $1.9 \times 10^{-1} \pm 0.01$ & $4.2 \times 10^{-3} \pm 0.02$ & $>20$ & $3.5 \times 10^{-2} \pm 0.02$ \\
$\mathbf{F - 2 - 2}$ & $3.2 \pm 0.01$ & $2.0 \pm 0.1$ & $>20$ & $2.9 \pm 0.05$ \\
$\mathbf{F - 2 - 3}$ & $1.0 \times 10^{-2} \pm 0.01$ & $5.5 \times 10^{-3} \pm 0.01$ & $2.5 \times 10^{-7} \pm 0.03$ & $2.6 \times 10^{-3} \pm 0.001$ \\
$\mathbf{1}$ & $1.91 \times 10^{-6} \pm 0.01$ & $0.95 \pm 0.005$ & $1.04 \times 10^{-5} \pm 0.031$ & $1.8 \times 10^{-4} \pm 0.01$ \\
$\mathbf{2}$ & $0.189 \pm 0.01$ & $0.085 \pm 0.005$ & $0.798 \pm 0.01$ & $3.8 \times 10^{-2} \pm 0.01$ \\
$\mathbf{3}$ & $1.0 \times 10^{-5} \pm 0.02$ & $1.0 \times 10^{-5} \pm 0.004$ & $1.02 \times 10^{-4} \pm 0.005$ & $0.40 \pm 0.01$ \\
$\mathbf{4}$ & $0.4 \pm 0.03$ & $1.7 \times 10^{-3} \pm 0.01$ & $0.4 \pm 0.01$ & $0.68 \pm 0.01$ \\
$\mathbf{5}$ & $1.5 \pm 0.01$ & $2.0 \times 10^{-3} \pm 0.003$ & $1.25 \pm 0.01$ & $1.23 \pm 0.01$ \\
$\mathbf{6}$ & $2.89 \pm 0.009$ & $2.0 \times 10^{-3} \pm 0.005$ & $3.68 \pm 0.08$ & $2.89 \pm 0.006$ \\
$\mathbf{7}$ & $1.03 \pm 0.01$ & $5.0 \times 10^{-3} \pm 0.005$ & $>4$ & $2.41 \pm 0.004$ \\
Camptothecin & $1.58 \times 10^{-3} \pm 0.01$ & $0.96 \pm 0.006$ & $1.28 \times 10^{-4} \pm 0.01$ & $5.5 \times 10^{-6} \pm 0.01$ \\
Podophyllotoxin & $8.7 \times 10^{-5} \pm 0.003$ & $0.85 \pm 0.009$ & $9.9 \times 10^{-5} \pm 0.005$ & $7.6 \times 10^{-3} \pm 0.05$ \\
Etoposide & $25 \times 10^{-3} \pm 0.002$ & $5.6 \times 10^{-3} \pm 0.0005$ & $0.54 \pm 0.009$ & $0.091 \pm 0.02$ \\
\hline
\end{tabular}

Bioassay-guided isolation procedures, using the activity against $\mathrm{KB}, \mathrm{HF}-6, \mathrm{MCF}-7$, and PC-3 cancer cell lines were carried out to define active components in this plant. Figure 2 shows the chromatographic fractionation of the HA extract monitored by the cytotoxic activity against PC-3 cells. Chromatographic fractionation of the HA extract afforded four fractions, two of which (F-1 and F-2), displayed potent cytotoxic activity against the four tested cell lines, principally against PC-3, both with $\mathrm{ED}_{50}$ values $\left(1 \times 10^{-5} \mu \mathrm{g} / \mathrm{mL}\right)$ greater than that displayed by the therapeutic drugs camptothecin $(0.96 \mu \mathrm{g} / \mathrm{mL})$, and etoposide $\left(5.6 \times 10^{-3} \mu \mathrm{g} / \mathrm{mL}\right)$ used as positive controls (Table 1).

Figure 2. Fractionation tree diagram of the HA extract, monitored by the cytotoxic activity against $\mathrm{PC}-3$ cell line in culture ( $\mathrm{ED}_{50}$ values in $\mu \mathrm{g} / \mathrm{mL}$ in square brackets).

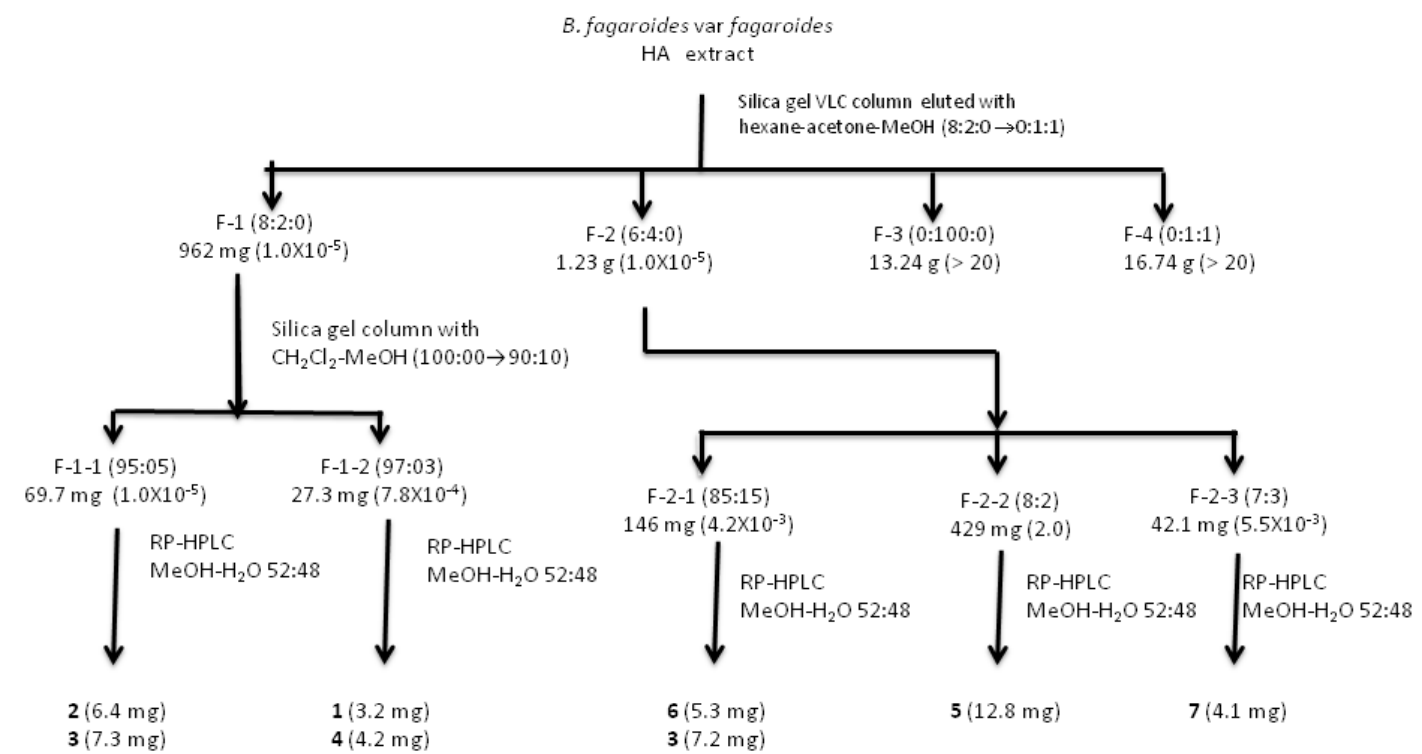


Chromatographic purification of F-1 afforded $\beta$-peltatin-A-methylether (2), 5'-desmethoxy- $\beta$ peltatin-A-methylether (3), desmethoxy-yatein (4), desoxypodophyllotoxin (5); while purification of F-2 afforded podophyllotoxin (1), burseranin, (6), and acetyl podophyllotoxin (7), which were identified by comparing their spectroscopic data with those previously described in the literature. The purity of isolated compounds was determined to be above of $95 \%$, based on the peak areas of their HPLC chromatograms, as well as by their ${ }^{1} \mathrm{H}-\mathrm{NMR}$ spectra. The structures of these compounds are shown in Figure 3.

Figure 3. Structures of compounds 1-7.

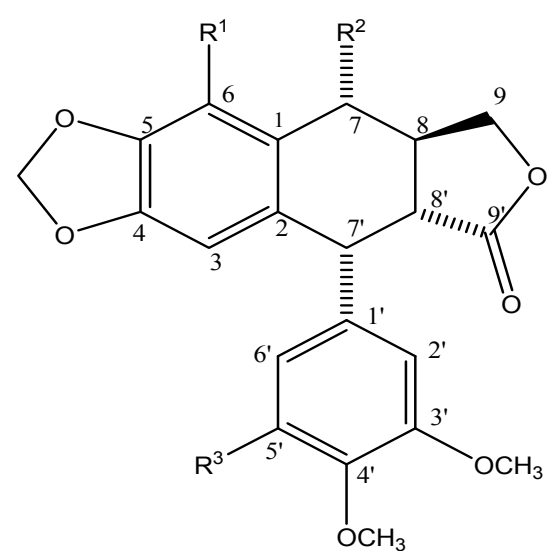

1: $\mathrm{R}^{1}=\mathrm{H}, \mathrm{R}^{2}=\mathrm{OH}, \mathrm{R}^{3}=\mathrm{OCH}_{3}$

2: $\mathrm{R}^{1}=\mathrm{OCH}_{3}, \mathrm{R}^{2}=\mathrm{H}, \mathrm{R}^{3}=\mathrm{OCH}_{3}$

3: $\mathrm{R}^{1}=\mathrm{OCH}_{3}, \mathrm{R}^{2}=\mathrm{R}^{3}=\mathrm{H}$

5: $\mathrm{R}^{1}=\mathrm{R}^{2}=\mathrm{H}, \mathrm{R}^{3}=\mathrm{OCH}_{3}$

7: $\mathrm{R}^{1}=\mathrm{H}, \mathrm{R}^{2}=\mathrm{OAc}, \mathrm{R}^{3}=\mathrm{OCH}_{3}$

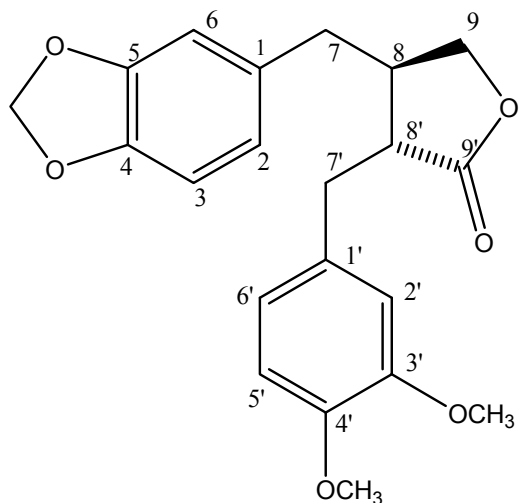

4

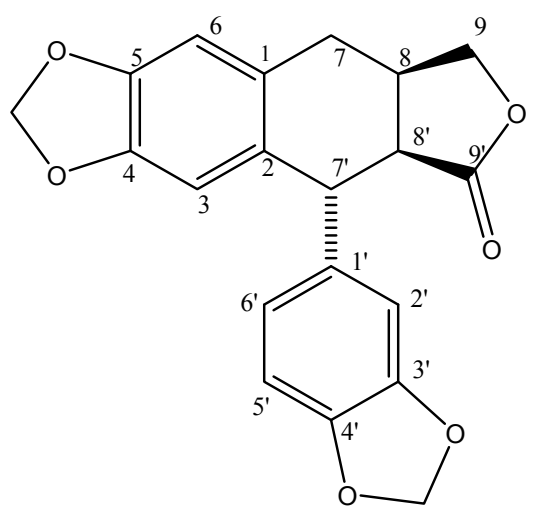

6

Podophyllotoxin (1) has traditionally been isolated from Podophyllum peltatum and Podophyllum emodi, but it has been found in around 20 genera such as Diphylleia, Dysosma, Catharanthus, Polygala, Anthriscus, Linum, Hyptis, Teucrium, Nepeta, Thuja, Juniperus, Cassia, Haplophyllum, Commiphora, and Hernandia [4]; $\beta$-peltatin-A-methylether (2) has been found in: Juniperus phoenicea [34], B. permollis [26], B. fagaroides [18], B. simaruba [35], Anthriscus sylvestris [36], Libocedrus plumose [37], and some Linum species and cultures [38-41], and its activity against A431, BC1, Col 2, HT, KB, LNCaP, Lu 1, Mel 2, U373, ZR-75-1 cancer cell lines [26], as well as its antitumor activity in the WA16 tumor system [18], have been described; 5 -desmethoxy- $\beta$-peltatin-A-methylether (3) has only been reported from $B$. fagaroides with activity against the WA16 tumor system [18]; desmethoxyyatein (4) showed activity against P388 lymphocytic leukemia cell line [42], and has been isolated from Hernandia ovigera [43,44], H. nymphaeifolia [42], Bursera schlechtendalii [24], and B. fagaroides [19]; desoxypodophyllotoxin (5) is the most widespread aryltetralin lignan, and has been found in a great variety of plants belonging to various genera such as Libocedrus [37], Linum [41], Bursera [19], Podophyllum [45-47], Anthriscus [36], Diphylleia [47], Dysosma [48], Hernandia [42], among others, and its cytotoxic activity is well known [4]; burseranin (6) has been only described as a constituent of $B$. graveolens, and showed activity against HT1080 cell line [22]; acetyl podophyllotoxin (7) is a constituent of Podophyllum, and has been obtained from podophyllotoxin for 
structure-activity studies [1]. Until now, Bursera has been reported to contain only podophyllotoxinrelated lignans, and this is the first report of the presence of podophyllotoxin (1) and its acetate 7 in a Bursera species.

Evaluation of the cytotoxic activity of the isolated compounds against the human cancer cell lines KB, PC-3, MCF-7, and HF-6 showed that, except for compounds 6 and 7, all the isolated compounds displayed high activity (Table 1). The results showed that compound $\mathbf{3}$ exhibited the most potent cytotoxicity against PC-3 cells, with $\mathrm{ED}_{50}$ value of $1.0 \times 10^{-5} \mu \mathrm{g} / \mathrm{mL}$; whereas podophyllotoxin (1) displayed the most potent cytotoxiciy against $\mathrm{KB}$ and MCF-7 cells with $\mathrm{ED}_{50}$ values of $1.91 \times 10^{-6}$, and $1.04 \times 10^{-5} \mu \mathrm{g} / \mathrm{mL}$, respectively. Remarkably, the cytotoxic activities of compounds $2-6$ toward PC-3 cells were greater than those of podophyllotoxin (1), as well as the anticancer chemotherapy drugs camptothecin and etoposide (Table 1). On the other hand, acetyl podophyllotoxin (7), was the only compound that was not active towards MCF-7 cells, and together with burseranin (6), showed slight activity against KB, and HF-6 tumor cell lines, showing better activity against PC-3 $\left(5.0 \times 10^{-3}\right.$, and $2.0 \times 10^{-3} \mu \mathrm{g} / \mathrm{mL}$, respectively), than etoposide. Compared with $\mathbf{1}$, compound 2 displayed moderate activity against $\mathrm{KB}, \mathrm{PC}-3$ and $\mathrm{MCF}-7$, with $\mathrm{ED}_{50}$ values ranging from 0.08 to $0.79 \mu \mathrm{g} / \mathrm{mL}$, and showed the best activity against HF-6 cells with $\mathrm{ED}_{50}=9.1 \times 10^{-2}$. Compound 3, displayed high activity against $\mathrm{KB}\left(\mathrm{ED}_{50}=1.0 \times 10^{-5} \mu \mathrm{g} / \mathrm{mL}\right), \mathrm{PC}-3\left(\mathrm{ED}_{50}=1.0 \times 10^{-5} \mu \mathrm{g} / \mathrm{mL}\right)$, and $\mathrm{MCF}-7$ $\left(\mathrm{ED}_{50}=1.02 \times 10^{-4} \mu \mathrm{g} / \mathrm{mL}\right)$, and was moderately active against HF-6 $\left(\mathrm{ED}_{50}=0.40 \mu \mathrm{g} / \mathrm{mL}\right)$. Compounds 4 and $\mathbf{5}$ displayed similar activities against the tested cell lines; the best activity was observed against PC-3 with $\mathrm{ED}_{50}$ values of $1.7 \times 10^{-3}$, and $2.0 \times 10^{-3} \mu \mathrm{g} / \mathrm{mL}$ respectively. It is interesting to point out that all of the lignans isolated from B. fagaroides var. fagaroides were active against PC-3 cells.

The cytotoxic activity of podophyllotoxin (1), desoxypodophyllotoxin (5) and their congeners is well known [49-52]. Some structure-activity relationship studies, using several podophyllotoxin analogues, showed that the core structure of deoxypodophyllotoxin (5) is responsible for this cytotoxicity. The extra methoxy group on the 6-position in 5 '-desmethoxy- $\beta$-peltatin-A-methylether (3) significantly changed the in vitro cytotoxicity when compared to desoxypodophyllotoxin (5). Compounds 4 and $\mathbf{6}$ which do not have the core structure of 5, displayed less potent activity against KB, MCF-7 and HF-6, and were more selective against PC-3 cell line (Table 1). Results here obtained confirm the structure-activity relationships previously described, and provide new cytotoxic data for compounds 3, 4, 6 and 7 that complement the knowledge of this type of compounds.

Although the cytotoxicity of podophyllotoxin (1) and desoxypodophyllotoxin (5) is well known, the cytotoxicity of $\mathbf{3}, \mathbf{4}, \mathbf{6}$, and 7 against the four cell lines tested, and of $\mathbf{2}$ against PC-3, MCF-7, and HF-6, is reported here for the first time.

\section{Experimental}

\subsection{General}

NMR spectra were acquired on a Varian Unity NMR spectrometer operating at $400 \mathrm{MHz}$ for ${ }^{1} \mathrm{H}$ and $100 \mathrm{MHz}$ for ${ }^{13} \mathrm{C}$ nuclei. Chemical shifts are listed in parts per million (ppm), referenced to $\mathrm{CDCl}_{3}$ and were made on the basis of ${ }^{1} \mathrm{H}-{ }^{1} \mathrm{H}$ gCOSY, ${ }^{1} \mathrm{H}-{ }^{1} \mathrm{H}$ TOCSY, NOESY, gHSQC and gHMBC spectral analysis as required. NMR experiments performed in $\mathrm{CDCl}_{3}$ are referenced to $\mathrm{Me}_{4} \mathrm{Si}(0 \mathrm{ppm})$. FABMS 
spectra in a matrix of $m$-nitrobenzyl alcohol or glycerol were recorded on a JEOL JMX-AX 505 HA mass spectrometer. All reagents and solvents used were analytical grade. Optical rotations were acquired with a Perkin-Elmer $241 \mathrm{MC}$ polarimeter $(10 \mathrm{~cm}, 1 \mathrm{~mL}$ cell $)$ at the sodium D line. High Performance Liquid Chromatography (HPLC) was performed using a Waters Delta Prep 4000 Module System equipped with a Waters 717 plus Autosampler and 996 Photodiode Array Detector (Waters Co., Milford, MA, USA), and a Xterra prep C18 column $(5 \mu \mathrm{m}, 7.8 \times 100 \mathrm{~mm})$ with $\mathrm{MeOH}-\mathrm{H}_{2} \mathrm{O}$ (52:48) as the isocratic eluent system, UV detection at $215 \mathrm{~nm}$ and a flow rate of $1 \mathrm{~mL} / \mathrm{min}$.

\subsection{Plant Material}

The bark of B. fagaroides var. fagaroides (H.B.K.) Engl. was collected in the village of Capula between Zacapu and Quiroga, Michoacán, México. Its identification was made at the herbarium of the Instituto Mexicano del Seguro Social (registration number-12 051 IMSSM) and the Institute of Botany, University of Guadalajara (IBUG-140 748), México.

\subsection{Extraction and Isolation}

The stem bark from B. fagaroides var. fagaroides was dried under dark conditions at room temperature for 10 days. The dry material $(1,420 \mathrm{~g})$ was milled to obtain $2-5 \mathrm{~mm}$ particles and then extracted by successive percolation with $n$-hexane $(3 \mathrm{~L})$ and then with $70 \%$ aqueous methanol $(\mathrm{MeOH}$, $3 \mathrm{~L}$ ) at room temperature (three times). The obtained extracts were evaporated to dryness with a rotary evaporator under reduced pressure producing $6.14 \mathrm{~g}$ ( $0.43 \%$ yield) of $n$-hexane, and $33 \mathrm{~g}$ (6.51\% yield) of hydroalcoholic dried extract, respectively. The hydroalcoholic extract was fractionated by percolation on a vacuum liquid chromatography column of silica gel $(47 \mathrm{~g})$ eluting with $n$-hexane-acetone-MeOH mixtures of increasing polarity to yield four fractions: F-1, $962 \mathrm{mg}(8: 2: 0,1.5 \mathrm{~L}), \mathrm{F}-2,1.23 \mathrm{~g}(6: 4: 0$, 1.5 L), F-3, $13.24 \mathrm{~g}(0: 100: 0,1.5 \mathrm{~L})$, and F-4, $16.74 \mathrm{~g}(0: 1: 1,3.5 \mathrm{~L})$.

F-1 was chromatographed on silica gel $(28.8 \mathrm{~g})$ with a gradient mixture of $\mathrm{CH}_{2} \mathrm{Cl}_{2}-\mathrm{MeOH}$ $(100: 0 \rightarrow 9: 1)$ to give two active fractions: F-1-1 (69.7 mg), eluted with $\mathrm{CH}_{2} \mathrm{Cl}_{2}-\mathrm{MeOH}$ (95:5), and F-1-2 (27.3 mg), eluted with $\mathrm{CH}_{2} \mathrm{Cl}_{2}-\mathrm{MeOH}$ (97:3). An aliquot of $22.5 \mathrm{mg}$ of F-1-1 was subjected to reverse-phase HPLC, to afford $6.4 \mathrm{mg}$ of $5^{\prime}$-desmethoxy- $\beta$-peltatin-A methylether $\left(3, \mathrm{t}_{\mathrm{R}}=3.38 \mathrm{~min}\right)$, and $7.3 \mathrm{mg}$ of desmethoxy-yatein $\left(4, t_{R}=4.21 \mathrm{~min}\right)$. The yields were based on peak areas of the HPLC chromatogram. An aliquot of $10.2 \mathrm{mg}$ of F-1-2 was subjected to reverse-phase HPLC with the same conditions than F-1-1 to yield $3.2 \mathrm{mg}$ of $\beta$-peltatin-A methylether $\left(2, \mathrm{t}_{\mathrm{R}}=13.95 \mathrm{~min}\right)$ and $4.2 \mathrm{mg}$ of deoxypodophyllotoxin $\left(5, t_{R}=10.55 \mathrm{~min}\right)$. The yields were based on peak areas of the HPLC chromatogram.

F-2 was subjected to column chromatography packed with silica gel $(50 \mathrm{~g})$ and eluted with a gradient system of $n$-hexane-acetone $(98: 2 \rightarrow 60: 40)$ obtaining 110 fractions of $25 \mathrm{~mL}$ each. One of the active fractions (F-2-1, 0.146 g), eluted with 85:15 $n$-hexane-acetone, was subjected to column chromatography on silica gel (4.5 g), eluted with a gradient of $n$-hexane-acetone $(95: 5 \rightarrow 8: 2)$ to give $18.5 \mathrm{mg}$ of a mixture of two compounds which were purified by HPLC with $\mathrm{MeOH}-\mathrm{H}_{2} \mathrm{O} 52: 48$ as the isocratic eluent system, to afford $5.3 \mathrm{mg}$ of acetyl podophyllotoxin $\left(7, \mathrm{t}_{\mathrm{R}}=8.08 \mathrm{~min}\right)$, and $7.2 \mathrm{mg}$ of desmethoxy-yatein $\left(4, t_{R}=4.10 \mathrm{~min}\right)$. An aliquot of the second fraction, F-2-2 (429 mg), eluted with $8: 2 n$-hexane:acetone, was further purified by HPLC providing $12.8 \mathrm{mg}$ of burseranin $\left(6, \mathrm{t}_{\mathrm{R}}=7.2 \mathrm{~min}\right)$. 
F-2-3, eluted with 7:3 $n$-hexane-acetone, was purified by HPLC with $\mathrm{MeOH}-\mathrm{H}_{2} \mathrm{O} 52: 48$ as the isocratic eluent system to yield $4.1 \mathrm{mg}$ of podophyllotoxin $\left(1, t_{R}=15.2 \mathrm{~min}\right)$. All the isolated compounds were identified using 1D and 2D NMR, optical rotation (OR), and HRMS analyses, and comparison with reported values.

\subsection{Spectral Data}

Podophyllotoxin (1). White amorphous powder; purity $=98 \%$; $[\alpha]^{24}{ }_{\mathrm{D}}-133^{\circ}\left(\mathrm{c} 0.012, \mathrm{CHCl}_{3}\right)$; IR $(\mathrm{KBr}) \gamma_{\max } 2932,1778.9,1727,1241.0,937.7 \mathrm{~cm}^{-1} ;{ }^{1} \mathrm{H}-\mathrm{NMR}\left(\mathrm{CDCl}_{3}\right) \delta 7.11(1 \mathrm{H}, \mathrm{s}, \mathrm{H}-6), 6.50(1 \mathrm{H}, \mathrm{s}$,

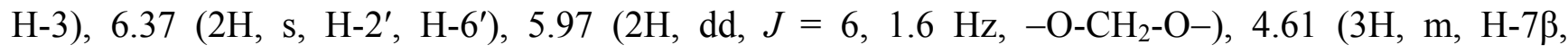
$\left.\mathrm{H}-9 \alpha, \mathrm{H}^{-} 7^{\prime}\right), 4.07$ (1H, dd, $\left.J=10.8,6 \mathrm{~Hz}, \mathrm{H}-9 \beta\right), 3.80\left(3 \mathrm{H}, \mathrm{s}, \mathrm{CH}_{3} \mathrm{O}-4^{\prime}\right), 3.75\left(6 \mathrm{H}, \mathrm{s}, \mathrm{CH}_{3} \mathrm{O}-3^{\prime}, \mathrm{CH}_{3} \mathrm{O}-5^{\prime}\right)$, $2.83\left(2 \mathrm{H}, \mathrm{m}, \mathrm{H}-8, \mathrm{H}-8^{\prime}\right) ;{ }^{13} \mathrm{C}-\mathrm{NMR}\left(\mathrm{CDCl}_{3}\right) \delta 174.63$ (C-9'), 152.83 (C-3', C-5'), 148.03 (C-5), 147.91 (C-4), 137.49 (C-4'), 135.63 (C-1'), 133.37 (C-2), 131.39 (C-1), 110.01 (C-3), 108.66 (C-2', C-6'), 106.5 (C-6), $101.66\left(\mathrm{O}-\mathrm{CH}_{2}-\mathrm{O}\right), 71.54(\mathrm{C}-9), 60.96\left(\mathrm{CH}_{3} \mathrm{O}-4^{\prime}\right), 56.6\left(\mathrm{CH}_{3} \mathrm{O}-3^{\prime}, \mathrm{CH}_{3} \mathrm{O}-5^{\prime}\right), 45.52(\mathrm{C}-8)$, $45.53\left(\mathrm{C}-8^{\prime}\right), 44.31\left(\mathrm{C}-7^{\prime}\right), 40.99$ (C-7); positive FAB-MS m/z 415 (20) [M + H] $]^{+}, 413$ (81), 391 (59), 355 (22), 327 (41), 467 (36), 239 (31), 221(90), 207 (100), 205 (57). These data match those in the literature [53].

$\beta$-Peltatin A methyl ether (2). White amorphous powder; purity $=96 \% ;[\alpha]^{24}-113^{\circ}\left(\mathrm{c} 0.011, \mathrm{CHCl}_{3}\right)$; ${ }^{1} \mathrm{H}-\mathrm{NMR}\left(\mathrm{CDCl}_{3}\right) \delta 6.8\left(2 \mathrm{H}, \mathrm{s}, \mathrm{H}-2^{\prime}, \mathrm{H}^{-6}{ }^{\prime}\right), 6.2(1 \mathrm{H}, \mathrm{s}, \mathrm{H}-3), 5.8\left(2 \mathrm{H}, \mathrm{s}, \mathrm{O}-\mathrm{CH}_{2}-\mathrm{O}\right), 4.5(1 \mathrm{H}, \mathrm{d}, J=4.4 \mathrm{~Hz}$, H-7'), 4.4 (1H, dd, $J=8.8 \mathrm{~Hz}, \mathrm{H}-9 \alpha), 3.9\left(3 \mathrm{H}, \mathrm{s}, \mathrm{CH}_{3} \mathrm{O}-6\right), 3.8(1 \mathrm{H}, \mathrm{dd}, J=10.4 \mathrm{~Hz}, \mathrm{H}-9 \beta), 3.7$ (3H, s, $\left.\mathrm{CH}_{3} \mathrm{O}-4^{\prime}\right), 3.68\left(6 \mathrm{H}, \mathrm{s}, \mathrm{CH}_{3} \mathrm{O}-3^{\prime}, \mathrm{CH}_{3} \mathrm{O}-5^{\prime}\right), 3.1$ (1H, dd, $\left.J=4.8,16 \mathrm{~Hz}, \mathrm{H} 7 \beta\right), 2.6\left(1 \mathrm{H}, \mathrm{m}, \mathrm{H}-8^{\prime}\right), 2.58$ $(1 \mathrm{H}, \mathrm{m}, \mathrm{H}-8), 2.4(1 \mathrm{H}, \mathrm{dd}, J=10.4,16 \mathrm{~Hz}, \mathrm{H}-7 \alpha) ;{ }^{13} \mathrm{C}-\mathrm{NMR}\left(\mathrm{CDCl}_{3}\right) \delta 175.2\left(\mathrm{C}-9^{\prime}\right), 152.9\left(\mathrm{C}-3^{\prime}\right.$, C-5'), 148.6 (C-4), 141.1 (C-6), 136.4 (C-1', C-4'), 135.1 (C-5), 132.0 (C-2), 121.2 (C-1), 109.0 (C-2', C-6'), 104.7 (C-3), $101.2\left(\mathrm{O}-\mathrm{CH}_{2}-\mathrm{O}\right), 72.6$ (C-9), $59.6\left(\mathrm{CH}_{3} \mathrm{O}-6\right), 56.7\left(\mathrm{CH}_{3} \mathrm{O}-3^{\prime}, \mathrm{CH}_{3} \mathrm{O}-5^{\prime}\right), 55.9$ $\left(\mathrm{CH}_{3} \mathrm{O}-4^{\prime}\right) 47.6\left(\mathrm{C}-8^{\prime}\right), 44.1\left(\mathrm{C}-7^{\prime}\right), 32.7$ (C-8), 27.8 (C-7); positive FAB-MS m/z 428 [M + H] ${ }^{+}$(66), 400 (13), 261 (32), 203 (15), 181 (24), 149 (51), 81 (100), 55 (98). These data match those in the literature $[18,35]$.

$5^{\prime}$-Desmethoxy- $\beta$-peltatin A methylether (3). White amorphous powder; purity $=99 \% ;[\alpha]^{24}-140^{\circ}$ (c $\left.0.018, \mathrm{CHCl}_{3}\right) ;{ }^{1} \mathrm{H}-\mathrm{NMR}\left(\mathrm{CDCl}_{3}\right) \delta 6.9\left(1 \mathrm{H}, \mathrm{d}, J=2.4 \mathrm{~Hz}, \mathrm{H}-2^{\prime}\right), 6.8\left(1 \mathrm{H}, \mathrm{d}, J=8.4 \mathrm{~Hz}, \mathrm{H}-5^{\prime}\right), 6.4$ $\left(1 \mathrm{H}, \mathrm{dd}, J=8,2 \mathrm{~Hz}, \mathrm{H}-6^{\prime}\right), 6.2(1 \mathrm{H}, \mathrm{s}, \mathrm{H}-3), 5.9\left(2 \mathrm{H}, \mathrm{d}, J=4.8 \mathrm{~Hz}, \mathrm{O}-\mathrm{CH}_{2}-\mathrm{O}\right), 4.5(1 \mathrm{H}, \mathrm{d}, J=4.4 \mathrm{~Hz}$, H-7'), $4.37(1 \mathrm{H}, \mathrm{t}, J=6.8 \mathrm{~Hz}, \mathrm{H}-9 \alpha), 4.0\left(3 \mathrm{H}, \mathrm{s}, \mathrm{CH}_{3} \mathrm{O}-6\right), 3.85(1 \mathrm{H}, \mathrm{dd}, J=10 \mathrm{~Hz}, \mathrm{H}-9 \beta), 3.8(3 \mathrm{H}, \mathrm{s}$, $\left.\mathrm{CH}_{3} \mathrm{O}-3^{\prime}\right), 3.7\left(3 \mathrm{H}, \mathrm{s}, \mathrm{CH}_{3} \mathrm{O}-4^{\prime}\right), 3.1(1 \mathrm{H}, \mathrm{dd}, J=4.8,16 \mathrm{~Hz}, \mathrm{H}-7 \alpha), 2.6\left(1 \mathrm{H}, \mathrm{m}, \mathrm{H}-8^{\prime}\right), 2.4(1 \mathrm{H}, \mathrm{m}$, $\mathrm{H}-8), 2.3(1 \mathrm{H}, \mathrm{dd}, J=10.4,16 \mathrm{~Hz}, \mathrm{H}-7 \beta) ;{ }^{13} \mathrm{C} \mathrm{NMR}\left(\mathrm{CDCl}_{3}\right) \delta 175.4\left(\mathrm{C}-9^{\prime}\right), 148.5(\mathrm{C}-5), 148.47$ (C-4), 148.1 (C-6), 140.9 (C-4'), 134.9 (C-1'), 133.94 (C-3'), 132.2 (C-2), 129.0 (C-1), 122.8 (C-6'), 114.7 (C-2'), 110.5 (C-5'), 104.6 (C-3), $101.1\left(\mathrm{O}-\mathrm{CH}_{2}-\mathrm{O}\right), 72.6(\mathrm{C}-9), 59.6\left(\mathrm{CH}_{3} \mathrm{O}-6\right), 56.2\left(\mathrm{CH}_{3} \mathrm{O}-3^{\prime}\right)$, $56.0\left(\mathrm{CH}_{3} \mathrm{O}-4^{\prime}\right), 47.5(\mathrm{C}-8), 43.5\left(\mathrm{C}-7^{\prime}\right), 32.4\left(\mathrm{C}-8^{\prime}\right), 29.9$ (C-7); positive FAB-MS m/z 370 (18) $[\mathrm{M}+\mathrm{H}]^{+}, 313(5), 279(7), 257(4), 178(4), 149$ (100), 95 (51), 57 (79). These data match those in the literature [18].

5'-Desmethoxyyatein (4). White amorphous powder; purity $=95 \% ;[\alpha]^{24}-20^{\circ}$ (c $0.018, \mathrm{CHCl}_{3}$ ); ${ }^{1} \mathrm{H}-\mathrm{NMR}\left(\mathrm{CDCl}_{3}\right) \delta 6.7\left(1 \mathrm{H}, \mathrm{d}, J=7.6 \mathrm{~Hz}, \mathrm{H}-6^{\prime}\right), 6.67\left(1 \mathrm{H}, \mathrm{d}, J=8 \mathrm{~Hz}, \mathrm{H}-5^{\prime}\right), 6.66\left(1 \mathrm{H}, \mathrm{s}, \mathrm{H}-2^{\prime}\right), 6.45$ 
$(1 \mathrm{H}, \mathrm{d}, J=7.6 \mathrm{~Hz}, \mathrm{H}-3), 6.44(1 \mathrm{H}, \mathrm{d}, J=8 \mathrm{~Hz}, \mathrm{H}-2), 6.43(1 \mathrm{H}, \mathrm{s}, \mathrm{H}-6), 5.9$ (2H, d, $\left.J=4 \mathrm{~Hz}, \mathrm{O}-\mathrm{CH}_{2}-\mathrm{O}\right)$, $4.1(1 \mathrm{H}, \mathrm{dd}, J=7.2,8.8 \mathrm{~Hz}, \mathrm{H}-9 \beta), 3.9\left(3 \mathrm{H}, \mathrm{s}, \mathrm{CH}_{3} \mathrm{O}-3^{\prime}\right), 3.84\left(3 \mathrm{H}, \mathrm{s}, \mathrm{CH}_{3} \mathrm{O}-4^{\prime}\right), 3.8(1 \mathrm{H}, \mathrm{m}, \mathrm{H}-9 \alpha)$, $2.9\left(1 \mathrm{H}, \mathrm{dd}, J=4.8 \mathrm{~Hz}, \mathrm{H}-7^{\prime}\right), 2.6(1 \mathrm{H}, \mathrm{dd}, J=6.8 \mathrm{~Hz}, \mathrm{H}-7 \beta), 2.5\left(2 \mathrm{H}, \mathrm{m}, \mathrm{H}-7 \alpha, \mathrm{H}-8^{\prime}\right), 2.48(1 \mathrm{H}, \mathrm{m}$, $\mathrm{H}-8) ;{ }^{13} \mathrm{C}$ NMR $\left(\mathrm{CDCl}_{3}\right) \delta 178.8\left(\mathrm{C}-9^{\prime}\right), 149.3\left(\mathrm{C}-3{ }^{\prime}\right), 148.2\left(\mathrm{C}-4^{\prime}\right), 148.1(\mathrm{C}-5), 146.6(\mathrm{C}-4), 131.8$ (C-1), $130.4\left(\mathrm{C}-1^{\prime}\right), 121.8$ (C-2), 121.6 (C-6'), 112. (C-2'), 109.0 (C-3), 111.4 (C-5'), 108.5 (C-6), $101.3\left(\mathrm{CH}_{2} \mathrm{O}_{2}\right), 71.37$ (C-9), $56.10\left(\mathrm{CH}_{3} \mathrm{O}-3^{\prime}\right), 56.18\left(\mathrm{CH}_{3} \mathrm{O}-4^{\prime}\right), 46.8\left(\mathrm{C}-8^{\prime}\right), 41.3(\mathrm{C}-8), 38.6(\mathrm{C}-7)$, 34.9 (C-7'); positive FAB-MS m/z 370 (18) [M + H] $]^{+}, 313$ (5), 279 (7), 257 (4), 178 (4), 149 (100), 95 (51), 57 (79). These data match those in the literature [24].

Desoxypodophyllotoxin (5). White amorphous powder; purity $=99 \%$; $[\alpha]^{24}{ }_{\mathrm{D}}-104^{\circ}\left(\mathrm{c} 0.018, \mathrm{CHCl}_{3}\right)$; ${ }^{1} \mathrm{H}-\mathrm{NMR}\left(\mathrm{CDCl}_{3}\right) \delta 7.1(1 \mathrm{H}, \mathrm{s}, \mathrm{H}-6), 6.5(1 \mathrm{H}, \mathrm{s}, \mathrm{H}-3), 6.37(2 \mathrm{H}, \mathrm{s}, \mathrm{H}-2$ ', H-6'), $6.0(2 \mathrm{H}, \mathrm{d}, J=1.2 \mathrm{~Hz}$, O-CH $2-\mathrm{O}), 4.6\left(1 \mathrm{H}, \mathrm{m}, \mathrm{H}-9 \alpha, \mathrm{H}-7^{\prime}\right), 4.0(1 \mathrm{H}, \mathrm{dd}, J=10.8 \mathrm{~Hz}, \mathrm{H}-9 \beta), 3.8\left(3 \mathrm{H}, \mathrm{s}, \mathrm{CH}_{3} \mathrm{O}-4^{\prime}\right), 3.7$ (6H, s, $\left.\mathrm{CH}_{3} \mathrm{O}-3^{\prime}, \mathrm{CH}_{3} \mathrm{O}-5^{\prime}\right), 2.8\left(3 \mathrm{H}, \mathrm{m}, \mathrm{H}-7 \alpha, \mathrm{H}-7 \beta, \mathrm{H}-8, \mathrm{H}-8^{\prime}\right) ;{ }^{13} \mathrm{C}-\mathrm{NMR}\left(\mathrm{CDCl}_{3}\right) \delta 174.6\left(\mathrm{C}-9^{\prime}\right), 152.8$ (C-3', C-5') 148.0 (C-5), 147.9 (C-4), 137.5 (C-4'), 135.6 (C-1'), 133.4 (C-2), 131.4 (C-1), 110.1 (C-3), 108.6 (C-6), 106.5 (C-6', C-2') $101.6\left(\mathrm{O}-\mathrm{CH}_{2}-\mathrm{O}\right), 71.5(\mathrm{C}-9), 60.9\left(\mathrm{CH}_{3} \mathrm{O}-4{ }^{\prime}\right), 56.5\left(\mathrm{CH}_{3} \mathrm{O}-3^{\prime}\right), 56.5$ $\left(\mathrm{CH}_{3} \mathrm{O}-5^{\prime}\right), 45.5$ (C-8), $45.5\left(\mathrm{C}-8^{\prime}\right), 44.3\left(\mathrm{C}-7^{\prime}\right), 40.9$ (C-7). These data match those in the literature [19].

Burseranin (6). White amorphous powder; purity $=96 \% ;[\alpha]^{24}{ }_{\mathrm{D}}+34^{\circ}\left(\mathrm{c} 0.012, \mathrm{CHCl}_{3}\right)$; ${ }^{1} \mathrm{H}-\mathrm{NMR}$ $\left(\mathrm{CDCl}_{3}\right) \delta 6.7\left(1 \mathrm{H}, \mathrm{d}, J=8.4 \mathrm{~Hz}, \mathrm{H}-5^{\prime}\right), 6.6\left(1 \mathrm{H}, \mathrm{d}, J=8.0 \mathrm{~Hz}, \mathrm{H}-6^{\prime}\right), 6.59$ (1H, s, H-2'), 6.3 (1H, s, H-3), $5.9\left(2 \mathrm{H}, \mathrm{s}, \mathrm{O}-\mathrm{CH}_{2}-\mathrm{O}-3^{\prime}, 4^{\prime}\right), 5.8(2 \mathrm{H}, \mathrm{s}),, 4.4(1 \mathrm{H}, \mathrm{dd}, J=9.2 \mathrm{~Hz}, \mathrm{H}-9 \alpha), 4.3(1 \mathrm{H}, \mathrm{d}, J=2.8 \mathrm{~Hz}$, H-7'), 3.92 (3H, s, $\left.\mathrm{CH}_{3} \mathrm{O}-6\right), 3.9$ (1H, dd, $\left.J=6.2 \mathrm{~Hz}, \mathrm{H}-9 \beta\right), 3.2$ (1H, m, H-8'), 2.9 (1H, m, H-8), 2.7 $(2 \mathrm{H}, \mathrm{m}, \mathrm{H}-7) ;{ }^{13} \mathrm{C}-\mathrm{NMR}\left(\mathrm{CDCl}_{3}\right) \delta 178.0\left(\mathrm{C}-9^{\prime}\right), 147.9(\mathrm{C}-4), 147.5\left(\mathrm{C}-4^{\prime}\right), 141.9\left(\mathrm{C}-3^{\prime}\right), 140.5(\mathrm{C}-6)$, 135.2 (C-5), 131.8 (C-2), 121.0 (C-1'), 120.7 (C-1), 119.8 (C-6'), 108.3 (C-2', C-5'), 104.1 (C-3), $100.72\left(\mathrm{O}-\mathrm{CH}_{2}-\mathrm{O}-4,5\right), 100.7\left(\mathrm{O}-\mathrm{CH}_{2}-\mathrm{O}-3^{\prime}, 4^{\prime}\right), 73.0$ (C-9), $59.5\left(\mathrm{CH}_{3} \mathrm{O}-6\right), 46.0\left(\mathrm{C}-8^{\prime}\right), 44.7\left(\mathrm{C}-7^{\prime}\right)$, 32.3 (C-8), 24.1 (C-7); positive FAB-MS m/z $382[\mathrm{M}+\mathrm{H}]^{+}$(0.4), 368 (0.4), 283 (0.6), 203 (0.5), 154 (40), $136(35), 95$ (75), 69 (91), 55 (100). These data match those in the literature [22].

Acetyl podophyllotoxin (7). White amorphous powder; purity $=99 \% ;[\alpha]^{24}{ }_{\mathrm{D}}-146.0^{\circ}\left(\mathrm{c} 0.011, \mathrm{CHCl}_{3}\right)$; ${ }^{1} \mathrm{H}-\mathrm{NMR}\left(\mathrm{CDCl}_{3}\right) \delta 6.7(1 \mathrm{H}, \mathrm{s}, \mathrm{H}-6), 6.5(1 \mathrm{H}, \mathrm{s}, \mathrm{H}-3), 6.3\left(2 \mathrm{H}, \mathrm{s}, \mathrm{H}-2{ }^{\prime}, \mathrm{H}-6{ }^{\prime}\right), 5.9(2 \mathrm{H}, \mathrm{d}, J=1 \mathrm{~Hz}$, O-CH $2-\mathrm{O}), 5.8(1 \mathrm{H}, \mathrm{d}, J=8.4 \mathrm{~Hz}, \mathrm{H}-7 \beta), 4.5\left(1 \mathrm{H}, \mathrm{d}, J=4 \mathrm{~Hz}, \mathrm{H}-7^{\prime}\right), 4.3(1 \mathrm{H}, \mathrm{dd}, J=6.2,9.0 \mathrm{~Hz}$, $\mathrm{H}-9 \alpha), 4.1(1 \mathrm{H}, \mathrm{dd}, J=9.4 \mathrm{~Hz}, \mathrm{H}-9 \beta), 3.75\left(3 \mathrm{H}, \mathrm{s}, \mathrm{CH}_{3} \mathrm{O}-4^{\prime}\right), 3.7\left(6 \mathrm{H}, \mathrm{s}, \mathrm{CH}_{3} \mathrm{O}-3^{\prime}, \mathrm{CH}_{3} \mathrm{O}-5^{\prime}\right), 2.8(2 \mathrm{H}$, m, H-8, H-8'), $2.1\left(3 \mathrm{H}, \mathrm{s}, \mathrm{CH}_{3} \mathrm{CO}\right) ;{ }^{13} \mathrm{C}-\mathrm{NMR}\left(\mathrm{CDCl}_{3}\right) \delta 173.7\left(\mathrm{C}-9^{\prime}\right), 171.4\left(\mathrm{CH}_{3} \mathrm{CO}\right), 152.6\left(\mathrm{C}-3^{\prime}\right.$, C-5'), 147.6 (C-4), 148.1 (C-5), 137.1 (C-4'), 134.9 (C-1'), 132.4 (C-1), 128.3 (C-2), 109.8 (C-6), 108.1 (C-2', C-6'), 107.1 (C-3), $101.7\left(\mathrm{O}-\mathrm{CH}_{2}-\mathrm{O}\right), 73.7$ (C-9), 71.5 (C-7), $60.9\left(\mathrm{CH}_{3} \mathrm{O}-4^{\prime}\right), 56.28$ $\left(\mathrm{CH}_{3} \mathrm{O}-3^{\prime}, \mathrm{CH}_{3} \mathrm{O}-5^{\prime}\right), 45.7\left(\mathrm{C}-7^{\prime}\right), 43.8\left(\mathrm{C}-8^{\prime}\right), 38.8(\mathrm{C}-8), 21.3\left(\underline{\mathrm{CH}_{3}} \mathrm{CO}\right)$; positive FAB-MS $m / z 456$ $[\mathrm{M}+\mathrm{H}]^{+}(58), 397(21), 313(9), 229$ (7), 185 (18), 154 (53), 136 (48), 95 (41), 77 (75), 55 (100), 41 (98). These data match those in the literature [19].

\subsection{Cytotoxicity Assay}

The in vitro cytotoxicity was measured by the sulphorhodamine B (SRB) (MP Biomedicals, LLC) protein staining assay [54,55] using KB (nasopharyngeal), HF-6 (colon), MCF7 (breast), and PC-3 (prostate) cancer cell lines. The cell cultures were maintained in RPMI-1640 medium supplemented 
with $10 \%$ fetal bovine serum, 5,000 units $/ \mathrm{mL}$ penicillin, $5 \mathrm{mg} / \mathrm{mL}$ streptomycin, $7.5 \% \mathrm{NaHCO}_{3}$, and cultured in a 96 -well microtiter plate $\left(10^{4}\right.$ cells $/ \mathrm{mL}, 190 \mu \mathrm{L} /$ well $)$ at $37{ }^{\circ} \mathrm{C}$ in a $5 \% \mathrm{CO}_{2}$-air atmosphere (100\% humidity). The cells at the $\log$ phase of growth were treated in triplicate $(n=3)$ with different concentrations of the test compounds $(0.16,0.8,4$ and $20 \mu \mathrm{g} / \mathrm{mL})$, and incubated for $72 \mathrm{~h}$. The cell concentration was determined by protein analysis. The optical density was measured at $590 \mathrm{~nm}$ with an ELISA-Reader (Molecular Devices, SPECTRA max plus 384). Results were expressed as the concentration that inhibits $50 \%$ of control growth after the incubation period $\left(\mathrm{IC}_{50}\right)$. The values were estimated from a semi-log plot of the extract concentration $(\mu \mathrm{g} / \mathrm{mL})$ against the percentage of viable cells. Camptothecin, etoposide, and podophyllotoxin were included as positive standards.

\subsection{Antitumor Activity}

Male BALB/c mice (6-8 weeks old, 22-26 g) were provided by the Centro de Investigación Biomedica de Occidente (CIBO-IMSS). A lymphoma L5178Y cell line was used derived from a thymic lineage (haplotype $\mathrm{H}-2 \mathrm{~d}$ ) tumor induced in DBA/2 mouse by methyl-cholanthrene adopted to an ascetic form, and maintained by intraperitoneal (i.p.) transplantation of $10 \times 10^{6}$ cells/mouse every 15 days in syngenic BALB/c mice [31]. For this study, all procedures involving animals were performed according to protocols approved by NOM-062-ZOO-1999. Animals were inoculated i.p. with $0.1 \mathrm{~mL}$ of suspension of fresh ascitic fluid, containing L5178Y lymphoma $\left(2 \times 10^{4}\right)$ cells/mouse on day zero. Treatment with HA extract started $24 \mathrm{~h}$ after inoculation at doses of 50 or $100 \mathrm{mg} / \mathrm{kg}$ oral rout/day during 15 days, each group containing five mice and were observed during 60 days.

\subsection{Statistical Analysis}

The results were analyzed using one-way ANOVA followed by Kaplan-Meier estimation of survival and Cox's regression through the statistical package SPSS V.15.

\section{Conclusions}

Bioassay-guided isolation of the hydroalcoholic extract obtained from the steam bark of B. fagaroides var. fagaroides identified a family of seven related lignans, among which podophyllotoxin (1) and acetyl podophyllotoxin (7) are described by the first time in Bursera. The presence of podophyllotoxin (1), together with six other related lignans in the cytotoxic extract of B. fagaroides var. fagaroides is noteworthy. In summary the cytotoxic and antitumor activities observed for $B$. fagaroides var. fagaroides are ascribable to the lignans present in this extract. Investigation of the podophyllotoxin-related lignans obtained from B. fagaroides var. fagaroides may lead to new cytostatic compounds, which could serve as the basis for new anti-tumor drugs.

\section{Acknowledgments}

Partial financial support from CONACYT, México (Grants No. 82851, 80980 and LN 56431) and UNAM (Grants IX201110, IN219309) is acknowledged. A. M. R. S. thanks CONACYT for fellowship (219701). 


\section{References}

1. Xu, H.; Lv, M.; Tian, X. A review on hemisynthesis, biosynthesis, biological activities, mode of action, and structure-activity relationship of podophyllotoxins: 2003-2007. Curr. Med. Chem. 2009, 16, 327-349.

2. Srivastava, V.; Negi, A.S.; Kumar, J.K.; Gupta, M.M.; Khanuja, S.P.S. Plant-based anticancer molecules: A chemical and biological profile of some important leads. Bioorg. Med. Chem. 2005, 13, 5892-5908.

3. Hartmann, J.T.; Lipp, H.P. Camptothecin and podophyllotoxin derivatives: Inhibitors of topoisomerase I and II-Mechanisms of action, pharmacokinetics and toxicity profile. Drug Saf. 2006, 29, 209-230.

4. Gordaliza, M.; Garcia, P.A.; del Corral, J.M.; Castro, M.A.; Gomez-Zurita, M.A. Podophyllotoxin: Distribution, sources, applications and new cytotoxic derivatives. Toxicon 2004, 44, 441-459.

5. Botta, B.; Monache, G.D.; Misiti, D.; Vitali, A.; Zappia, G. Aryltetralin lignans: Chemistry, pharmacology and biotransformations. Curr. Med. Chem. 2001, 8, 1363-1381.

6. Becerra, J.X. Evolution of Mexican Bursera (Burseraceae) inferred from ITS, ETS, and 5S nuclear ribosomal DNA sequences. Mol. Phylogenet. Evol. 2003, 26, 300-309.

7. Becerra, J.X.; Venable, D.L. Nuclear ribosomal DNA phylogeny and its implications for evolutionary trends in Mexican Bursera (Burseraceae). Am. J. Bot. 1999, 86, 1047-1057.

8. Rzedowski, J.; Kruze, H. Algunas tendencias evolutivas en Bursera (Burseraceae). Taxon 1979, 28, 103-116.

9. Peter, C.M.; Purata, S.E.; Chibnik, M.; Brosi, B.J.; López, A.M.; Amrosio, M. The life and times of Bursera glabrifolia (H.B.K.) Engl. In México: A parable for ethnobotany. Econ. Bot. 2003, 57, 431-441.

10. Case, R.J.; Tucker, A.O.; Maciarello, M.J.; Wheeler, K.A. Chemistry and ethnobotany of commercial incense copals, copal blanco, copal oro, and copal negro, of North America. Econ. Bot. 2003, 57, 189-202.

11. Nakanishi, T.; Inatomi, Y.; Satomi, A.; Yamada, T.; Fukatsu, H.; Murata, H. New luteolin 3-O-acylated rhamnosides from leaves of Bursera graveolens. Heterocycles 2003, 60, 2077-2083.

12. Souza, M.P.; Machado, M.I.L.; Braz-Filho, R. Six flavonoids from Bursera leptophloeos. Phytochemistry 1989, 28, 2467-2470.

13. Peraza-Sánchez, S.R.; Salazar-Aguilar, N.E.; Peña-Rodríguez, L.M. A New triterpene from the resin of Bursera simaruba. J. Nat. Prod. 1995, 58, 271-274.

14. Syamasundar, K.V.; Mallavarapu, G.R. Two triterpenoid lactones from the resin of Bursera delpechiana. Phytochemistry 1995, 40, 337-339.

15. Barreira, E.S.; Queiroz-Monte, F.J.; Braz-Filho, R.A New furanosesquiterpene from Bursera leptophloeos. Nat. Prod. Lett. 1996, 8, 285-289.

16. Noge, K.; Becerra, J.X. Germacrene D, a common sesquiterpene in the genus Bursera (Burseraceae). Molecules 2009, 14, 5289-5297.

17. García-Gutiérrez, H.A.; Cerda-García-Rojas, C.M.; Hernández-Hernández, J.D.; Román-Marín, L.U.; Joseph-Nathan, P. Oxygenated verticillene derivatives from Bursera suntui. Phytochemistry 2008, $69,2844-2848$. 
18. Bianchi, E.; Sheth, K.; Cole, J.R. Antitumor agents from Bursera fagaroides (Burseraceae). (Beta-peltatin-A-methylether and 5'-desemethoxy-beta-peltatin-A-methylether). Tetrahedron Lett. 1969, 10, 2759-2762.

19. Velazquez-Jimenez, R.; Torres-Valencia, J.M.; Cerda-Garcia-Rojas, C.M.; Hernandez-Hernandez, J.D.; Roman-Marin, L.U.; Manriquez-Torres, J.J.; Gomez-Hurtado, M.A.; Valdez-Calderon, A.; Motilva, V.; Garcia-Maurino, S.; et al. Absolute configuration of podophyllotoxin related lignans from Bursera fagaroides using vibrational circular dichroism. Phytochemistry 2011, 72, 2237-2243.

20. Maldini, M.T.; Montoro, P.; Piacente, S.; Pizza, C. Phenolic Compounds from Bursera simaruba Sarg. Bark: Phytochemical investigation and quantitative analysis by tandem mass spectrometry. Phytochemistry 2009, 70, 641-649.

21. Jutiviboonsuk, A.; Zhang, H.; Tan, G.T.; Ma, C.; Hung, N.V.; Cuong, N.M.; Bunyapraphatsara, N.; Soejarto, D.D.; Fong, H.H.S. Bioactive constituents from roots of Bursera tonkinensis. Phytochemistry 2005, 66, 2745-2751.

22. Nakanishi, T.; Inatomi, Y.; Murata, H.; Shigeta, K.; Iida, N.; Inada, A.; Murata, J.; Farrera, M.A.; Iinuma, M.; Tanaka, T.; Tajima, S.; Oku, N. A new and known cytotoxic aryltetralin-type lignans from stems of Bursera graveolens. Chem. Pharm. Bull. 2005, 53, 229-231.

23. Cole, J.R.; Bianchi, E.; Trumbull, E.R. Antitumor agents from Bursera microphylla (Burseraceae) II: Isolation of a new lignan-burseran. J. Pharm. Sci. 1969, 58, 175-176.

24. McDoniel, P.B.; Cole, J.R. Antitumor activity of Bursera schlechtendalii (Burseraceae): Isolation and structure determination of two new lignans. J. Pharm. Sci. 1972, 61, 1992-1994.

25. Peraza-Sanchez, S.R.; Peña-Rodríguez, L.M. Isolation of picropolygamain from the resin of Bursera simaruba. J. Nat. Prod. 1992, 55, 1768-1771.

26. Wickramaratne, D.B.M.; Mar, W.; Chai, H.; Castlllo, J.J.; Farnsworth, N.R.; Soejarto, D.D.; Cordell, G.A.; Pezzuto, I.M.; Kinghorn, A.D. Cytotoxic constituents of Bursera permollis. Planta Med. 1995, 61, 80-81.

27. Jolad, S.D.; Wiedhopf, R.M.; Cole, J.R. Cytotoxic agents from Bursera morelensis (Burseraceae): Deoxypodophyllotoxin and a new lignan, 5'-desmethoxydeoxypodophyllotoxin. J. Pharm. Sci. 1977, 66, 892-893.

28. Rzedowski, J.R.M.L.; de Rzedowski, G.C. Inventario del conocimiento taxonómico, así como de la diversidad y del endemismo regionales de las especies Mexicanas de Bursera (Burseraceae). Acta Botánica Mexicana 2005, 70, 85-111.

29. Aguilar, A.; Camacho, J.R.; Chino, S.; Jacquez, P.; López, M.E. Herbario medicinal del instituto mexicano del seguro social. In Información Etnobotánica; Instituto Mexicano del Seguro Social: México D.F., Mexico, 1994; p. 28.

30. Hernández, F. Historia de las Plantas de Nueva España; Universidad Nacional Autónoma de México: México D.F., Mexico, 1942; pp. 551-553.

31. Puebla-Pérez, A.M.; Huacuja, L.; Rodríguez, G.; Lozoya, X.; Zaitseva-Petrovna, G.; Villaseñor-García, M. Cytotoxic and antitumor activity from Bursera fagaroides ethanol extract in mice with L5178Y lymphoma. Phytother. Res. 1998, 12, 545-548.

32. Rosas-Arreguin, P.; Arteaga-Nieto, P.; Reynoso-Orozco, R.; Villagomez-Castro, J.C.; Sabanero-Lopez, M.; Puebla-Perez, A.M.; Calvo-Mendez, C. Bursera fagaroides, Effect of an ethanolic extract on ornithine decarboxylase (ODC) activity in vitro and on the growth of Entamoeba histolytica. Exp. Parasitol. 2008, 119, 398-402. 
33. Huacuja, R.L.; Delgado, N.M.; Carranco, L.A.; Reyes, L.R.; Rosado, G.A. Agglutinating and immobilizing activity of an ethanol extract of Bursera fagaroides on human and other mammalian spermatozoa. Arch. Invest. Med. (Mex) 1990, 21, 393-398.

34. Cairnes, D.A.; Ekundayo, O.; Kingston, D.G. Plant anticancer agents. X. Lignans from Juniperus Phoenicea. J. Nat. Prod. 1980, 43, 493-497.

35. Noguera, B.; Díaz, E.; García, M.V.; San Feliciano, A.; López-Perez, J.L.; Israel, A. Anti-Inflammatory activity of leaf extract and fractions of Bursera simaruba (L.) Sarg (Burseraceae). J. Ethnopharmacol. 2004, 92, 129-133.

36. Hendrawati, O.; Woerdenbag, H.J.; Michiels, P.J.A.; Aantjes, H.G.; van Dam, A.; Kayser, O. Identification of lignans and related compounds in Anthriscus sylvestris by LC-ESI-MS/MS and LC-SPE-NMR. Phytochemistry 2011, 72, 2172-2179.

37. Perry, N.B.; Foster, L.M. Antitumour lignans and cytotoxic resin acids from a New Zealand gymnosperm, Libocedrus plumose. Phytomedicine 1994, 1, 233-237.

38. Berlin, J.; Wray, V.; Mollenschott, C.; Sasse, F. Formation of $\beta$-peltatin-A methyl ether and coniferin by root cultures of Linum flavum. J. Nat. Prod. 1986, 49, 435-439.

39. Kranz, K.; Petersen, M. $\beta$-Peltatin 6-O-methyltransferase from suspension cultures of Linum nodiflorum. Phytochemistry 2003, 64, 453-458.

40. Federolf, K.; Alfermann, A.W.; Fuss, E. Aryltetralin-Lignan formation in two different cell suspension cultures of Linum album: Deoxypodophyllotoxin 6-hydroxylase, a key enzyme for the formation of 6-methoxypodophyllotoxin. Phytochemistry 2007, 68, 1397-1406.

41. Schmidt, T.J.; Hemmati, S.; Klaes, M. Konuklugil, B.; Mohagheghzadeh, A.; Ionkova, I.; Fuss, E.; Alfermann, A.W. Lignans in flowering aerial parts of Linum species-chemodiversity in the light of systematics and phylogeny. Phytochemistry 2010, 71, 1714-1728.

42. Pettit, G.R.; Meng, Y.; Gearing, R.P.; Herald, D.L.; Pettit, R.K.; Doubek, D.L.; Chapuis, J.C.; Tackett, L.P. Antineoplastic agents. 522. Hernandia peltata (Malaysia) and Hernandia nymphaeifolia (Republic of Maldives). J. Nat. Prod. 2004, 67, 214-220.

43. Ito, C.; Itoigawa, M.; Ogata, M.; Mou, X.Y.; Tokuda, H.; Nishino, H.; Furukawa, H. Lignans as anti-tumor-promoter from the seeds of Hernandia ovigera. Planta Med. 2001, 67, 166-168.

44. Ito, C.; Matsui, T.; Wu, T.-S.; Furukawa, H. Isolation of 6,7-demethylenedesoxypodophyllotoxin from Hernandia ovigera. Chem. Pharm. Bull. 1992, 40, 1318-1321.

45. Jackson, D.E.; Dewick, P.M. Aryltetralin lignans from Podophyllum hexandrum and Podophyllum peltatum. Phytochemistry 1984, 23, 1147-1152.

46. Jackson, D.E.; Dewick, P.M. Tumour-inhibitory aryltetralin lignans from Podophyllum pleianthum. Phytochemistry 1985, 24, 2407-2409.

47. Broomhead, A.J.; Dewick, P.M. Tumour-inhibitory aryltetralin lignans in Podophyllum versipelle, Diphylleia cymosa and Diphylleia grayi. Phytochemistry 1990, 29, 3831-3837.

48. Jiang, R.-W.; Zhou, J.-R.; Hon, P.-M.; Li, S.-L.; Zhou, Y.; Li, L.-L.; Ye, W.-C.; Xu, H.-X.; Shaw, P.-C.; But, P.P.-H. Lignans from Dysosma Wersipellis with inhibitory effects on prostate cancer cell lines. J. Nat. Prod. 2007, 70, 283-286.

49. Hadimani, S.B.; Tanpure, R.P.; Bhat, S.V. Asymmetric total synthesis of (-)-podophyllotoxin. Tetrahedron Lett. 1996, 37, 4791-4794. 
50. Middel, O.; Woerdenbag, H.J.; Van Uden, W.; Van Oeveren, A.; Jansen, J.F.G.A.; Feringa, B.L.; Konings, A.W.T.; Pras, N.; Kellogg, R.M. Synthesis and cytotoxicity of novel lignans. J. Med. Chem. 1995, 38, 2112-2117.

51. Cho, S.J.; Tropsha, A.; Suffness, M.; Cheng, Y.C.; Lee, K.H. Antitumor agents. 163. Threedimensional quantitative structure-activity relationship study of 4'-O-demethylepipodophyllotoxin analogs using the modified CoMFA/q2-GRS approach. J. Med. Chem. 1996, 39, 1383-1395.

52. Thurston, L.S.; Irie, H.; Tani, S.; Han, F.-S.; Liu, Z.-C.; Cheng, Y.-C.; Lee, K.-H. Antitumor agents. 78. Inhibition of human DNA topoisomerase II by podophyllotoxin and $\alpha$-peltatin analogs. J. Med. Chem. 1986, 29, 1547-1550.

53. Hartwell, J.L.; Schrecker, A.W. Components of podophyllin V. The constitution of podophyllotoxin. J. Am. Chem. Soc. 1951, 73, 2909-2916.

54. Geran, R.I.N.H.; Macdonald, M.M.; Schumacher, A.M.; Abbott, B.J. Protocols for screening chemical agents and natural products against animal tumours and other biological systems. Cancer Chemother. Rep. 1972, 3, 51-61.

55. Houghton, P.; Fang, R.; Techatanawat, I.; Steventon, G.; Hylands, P.J.; Lee, C.C. The sulphorhodamine (SRB) assay and other approaches to testing plant extracts and derived compounds for activities related to reputed anticancer activity. Methods 2007, 42, 377-387.

Sample Availability: Samples of the compounds 1-7 are available from the authors.

(C) 2012 by the authors; licensee MDPI, Basel, Switzerland. This article is an open access article distributed under the terms and conditions of the Creative Commons Attribution license (http://creativecommons.org/licenses/by/3.0/). 